Europe's Journal of Psychology, 8(1), pp. 74-94, doi:10.5964/ejop.v8i1.299

www.ejop.org

\title{
Parent - Adolescent Communication and Delinquency: A Comparative Study in Kolkata, India
}

Tanusree Moitra

University of Calcutta, Kolkata, India

Indrani Mukherjee

University of Calcutta, Kolkata, India

\section{Abstract}

The present study assessed the impact of one of the dimension of parenting practices, parent-adolescent communication, on the development of delinquent behavior. The data was collected from 200 adolescents (100 delinquents and 100 non-delinquents) aged 11-18 years. Results suggested a significant difference between delinquent and non-delinquent adolescents - in terms of their perception of satisfactory parental communication. Further analyses revealed that both mother's and father's separate communication as well as their interaction effect was linked to the development of delinquent behavior. It was further noted that a satisfactory mother-adolescent communication was much more important compared to the father-adolescent communication in the present context. Furthermore, age of the adolescent was also related to delinquency and it was observed that early adolescence was a richer breeding ground of delinquency, although a satisfactory parental communication was crucial throughout the adolescent period to serve as a protective factor against delinquency. The theoretical and practical implications of the findings are discussed.

Keywords: Mother-Adolescent Communication; Father-Adolescent Communication; Age; Delinquency; Kolkata; India

This is an open access article distributed under the terms of the Creative Commons Attribution License (http://creativecommons.org/licenses/by/3.0), which permits unrestricted use, distribution, and reproduction in any medium, provided the original work is properly cited. 


\section{Introduction}

There is considerable evidence to suggest that the family plays an important role in the development of adolescent delinquent behavior. Family serves as an effective agent of socialization. From the very first day of a child's life the process of socialization begins, and parents are the primary source of this process. The period of adolescence is that phase of life when strong parent-child attachment is essential for both the normal development of adolescents, both biological and psychological, but it can also be a period that is disruptive for family socialization (Granic, Dishion, Hollenstein, \& Patterson, 2002; Steinberg, 1988). Studies have shown that, if the bond with the parent is weakened, the probability of risk behavior increases. On the other hand, if this emotional bond is strengthened, the probability of a problem type of behavior decreases (Hirschi, 1969). Furthermore, parental bonding strongly decreases adolescent involvement in delinquency (Cernkovich \& Giordano, 1987; Hirschi, 1969; Warr, 1993). Indeed, warm, loving and responsive parenting contributes to strengthen parentadolescent bonds and reduces the likelihood of delinquent involvement (Smith \& Krohn, 1995). The stronger this attachment bond, the more likely the adolescent is to take it into account when he or she contemplates a criminal act (Hirschi, 1969). Hirschi (1969) suggests that low levels of emotional attachment to parents predict involvement in delinquency regardless of race/ ethnicity, class or peers delinquency. Therefore a great deal of research has emphasized the importance of children's attachment with parental figures in decreasing the likelihood of delinquency (Bachman, 1970; Bandura \& Walters, 1959; Glueck \& Glueck, 1962; Gold, 1963; Hirschi, 1969).

Communication is a significant facet of parent adolescent attachment. For example, if parent adolescent communication is indifferent or negative, children are likely to encounter greater difficulties when growing up. It is through this process of communication that a child develops his or her patterns of cognition, knowledge, attitude toward the external world. It has been assumed that a child learns to regulate his or her emotions through specific cognitions, which in turn are developed on the basis of healthy parent child interactions (Garnefski, Rieffe, Jellesma, Terwogt, \& Kraaij, 2007). Studies on parent adolescent communication reported that parental communication has a strong relationship to the well-being of the adolescent (Greenberg, Siegel, \& Leitch, 1983), and the lack of closeness with parents (Kandel \& Davies, 1982; Parker, Tupling, \& Brown, 1979) or a lower level of parental influence (Chrispin, 1998) correlates with a higher degree of behavioral problems in adolescents. 
In past decades numerous researches have consistently demonstrated that parent adolescent communication is positively related to the adolescents' academic achievement (Masselam, Marcus, \& Stunkard, 1990), self-esteem (Brage \& Meredith, 1994; Demo, Small, \& Savin-Williams, 1987; Enger et al., 1994) and mental health (Collins, Newman, \& Mckenry, 1995; Hanson, 1986), as well as inversely related to adolescent Ioneliness and depression (Brage \& Meredith, 1994), drug and alcohol use, and other deviant behaviors (Barnes, Farrell, \& Banerjee, 1994; Hawley, Shear, Stark, \& Goodman, 1984; Johnson, SU, Gerstein, Shin, \& Hoffman, 1995; Kafka \& London, 1991; Miller, King, Shain, \& Naylor, 1992). Also it has been observed that family communication between parents and adolescents, especially in socioeconomically disadvantaged families, play a significant role in the development of various kinds of psychosocial adjustment among adolescents and young adults (Rueter \& Koerner, 2008).

Research on adolescents at risk of mental health or conduct problems, has identified healthy parent-child communication as a protective factor, whereas negative communication between parents and children act as a risk factor for various psychosocial adjustments in the case of adolescents (Liu, 2003; Musitu Ochoa, Estevez Lopez, \& Emler, 2007). Open parent child communication has been linked with low levels of adolescent risk behavior and high psychosocial adjustment (Guilamo-Ramos, Jaccard, Dittus \& Bouris, 2006; Kotchick, Dorsey, Miller, \& Forehand, 1999; Yu et al., 2006). It is also reported that a positive parent child communication leads to less sexual risk-taking behaviors. Clark \& Shields (1997) found that adolescents who lack open parental communication are more prone towards serious delinquency. So, overall an open communication between parent and adolescent may serve as a protective factor for children against the development of depression and anxiety and engagement in antisocial activities (Barnes \& Olson, 1985). In addition, open communication between parent and adolescent is positively related with the development of the adolescent's moral reasoning, academic achievement and self-esteem (Hartos \& Power, 2000; Holstein, 1972; Stanley, 1978). Johnson \& Lobitz (1974) have demonstrated that those parents who engage in high rates of negative interactions with their children increase the deviant behavior of their children.

As such, the desirable benefits of open and clear parent adolescent communication are generally endorsed in the existing research literature. However, communication is a complex, dynamic and reciprocal process (Jaccard, Dodge, \& Dittus, 2002), so to understand the process of communication from the perspective of both mother and father is essential, but only few studies have explored the gender of the parent as a 
construct that might contribute to our understandings of how the parental attachment affects adolescent delinquency. Hoeve et al., (2009) found that studies generally focus on one parent or both parents without differentiating the gender of the parent. Although mothers usually spend more time taking care of their children, it is important to consider parenting effects of both mother and father - because apart from quantity of the time father and mother spend with their children, there are indications that parental involvement is also qualitatively different (Videon, 2005). For example, fathers more often tend to give instrumental care whereas mothers provide more emotional care (Youniss \& Smollar, 1985). Therefore it may be desirable to examine data from both parents' perception of open and clear communication with their children. But no data are available to differentiate maternal and paternal communication with children and the development of delinquency (Xiao, Li, \& Stanton, 2011). Research was conducted for instance on mothers' and fathers' communication in relation to adolescents' psychological health, e.g. depression (Liu, 2003) but not regarding delinquency. Also there are no studies that discuss the relationship between mother and father communication with their children in the development of delinquency in an Indian context. So, in the present study an attempt has been made to understand the relationship between mother/ father - adolescent communication and delinquency in India. More specifically, the research question addressed in this study is: Are there any differences between maternal and paternal communication with their adolescent child (as perceived by the adolescent) and how do they relate to the development of delinquent behavior?

Method

Sample

The data has been collected from two groups of adolescents living in the city of Kolkata, India. Kolkata is the commercial capital of Eastern India, located on the east bank of the Hooghly River. At present the population of the city is 4.4 million (Office of the Registrar General and Census Commissioner, 2011).

The first group consisted of 100 delinquent boys, residents of a Correction home located in the city of Kolkata. The age range for this group was 11 to 18 ( $M=15.52$ years; $S D=$ 1.62). The second group used in the research consisted of 100 regular school adolescents who lived with their parents and had no history of delinquency and no police record. The age range for this group was again 11 to $18(M=16.13$ years; SD = 1.93). The demographic characteristics of the participants are presented in Table 1. 
Table 1 Demographic description of the sample

\begin{tabular}{|c|c|c|}
\hline Demographic Variables & Delinquent & Non-delinquent \\
\hline \multicolumn{3}{|l|}{ 1. Education } \\
\hline - No School & 32 & 00 \\
\hline - Elementary School & 41 & 18 \\
\hline - Middle School & 25 & 72 \\
\hline - High School & 02 & 10 \\
\hline \multicolumn{3}{|l|}{ 2. Father's Education } \\
\hline - No School & 32 & 00 \\
\hline - Elementary School & 56 & 24 \\
\hline - Middle School & 00 & 45 \\
\hline - High School & 12 & 31 \\
\hline \multicolumn{3}{|l|}{ 3. Mother's Education } \\
\hline - No School & 69 & 18 \\
\hline - Elementary School & 31 & 42 \\
\hline - Middle School & 00 & 33 \\
\hline - High School & 00 & 09 \\
\hline \multicolumn{3}{|c|}{ 4. Mother's Employment Status } \\
\hline - Working & 73 & 22 \\
\hline - Non-working & 27 & 78 \\
\hline 5. Average no. of sibling & 02 & 01 \\
\hline \multirow[t]{2}{*}{ 6. Average Family Income } & $4820 \mathrm{INR} /$ per month & $6500 \mathrm{INR} /$ per month \\
\hline & $\begin{array}{l}\text { App. } £ 75 / \text { per } \\
\text { month }\end{array}$ & $\begin{array}{l}\text { App. £ 100/ per } \\
\text { month }\end{array}$ \\
\hline \multicolumn{3}{|l|}{ 7. Substance Abuse } \\
\hline - Yes & 94 & 03 \\
\hline - No & 06 & 97 \\
\hline
\end{tabular}

Measures

Independent Variable. Perception of Communication Satisfaction Questionnaire (PCS; Hecht, 1978) is a 19 item questionnaire, used to measure perceived satisfaction and dissatisfaction with parental communication as expressed by children. Participants are asked to use a 7-point agree-to-disagree scale to rate the degree to which each item 
describes their communication with their parents. A score of 7 indicates 'most satisfactory communication' and score of 1 indicates 'least satisfactory communication'. The response to each item is categorized into 'high' or 'low' by median split, which is 57 . Higher score represents greater satisfaction - and presumably a stronger attachment. A modified and adapted version of Hecht's original inventory has been used (Prof. I. Mukherjee, Dept. of Applied Psychology, University of Calcutta, India).

First, the original Perception of Communication Satisfaction scale by Hecht was translated into Bengali language (local language spoken in Kolkata, India). Two separate forms were prepared one for mother's PCS and another to measure father's PCS score. Second, these two scales were administered to 100 male school adolescents living with both parents. In order to determine the reliability of the modified version Cronbach's Alpha was computed. The coefficient was .84 for communication with mother and .78 for communication with father scale. Item-total correlations were computed for all the 19 items. Most of the items were significant at .05 level and a few of them significant at a .01 level.

Dependent Variable. Behavior Deviance Scale was developed by Chauhan \& Aurora (1989), it is a 30-item scale designed to understand the extent of delinquent behavior present in the case of adolescents. Officially recorded delinquency has traditionally been the most common measure. However, official delinquency has the potential disadvantage that it may be a measure not only of delinquency but also of the behavior of police and court personnel (Lerman, 1968). Therefore, a standardized scale has been used along with the official delinquency measure. This measure is completed by two other persons (for each juvenile) who know the participant very well. In this study, it was completed by two other delinquents who were residing in the same Correction home and who knew the respondent closely. Items were arranged in a 5point scale, from very high 5; high 4; moderate 3; low 2; and very low 1. The final score in this case is the average of the total scores given by both the juveniles. High score indicate lower deviance. Examples of the items: "to steal", "to be disloyal", "to form company with bad people" etc. The Cronbach's Alpha reliability score was .79 and the validity of the scale was .88 . 
Procedure

The study was divided into two phase. In the first phase, before visiting the Correction home, a written proposal was given to the Magistrate of the Juvenile Justice Board, Kolkata, West Bengal, India, explaining the purpose of the study. After getting the permission from the Magistrate, the Superintendent of the Correction home was contacted by the first author concerning the purpose of the study and seeking his permission to visit the home. After obtaining permission a tentative time schedule was developed in discussion with the staff of the home. Both measures (i.e. Perception of Communication Satisfaction and Behavior Deviance Scale) were administered directly to delinquent participants using the interview method under close supervision by the staff of the home. The interview session for each participant lasted for two days for approximately half-an-hour daily. In order to comply with APA's ethical guidelines, the interview was conducted only with those participants who gave their consent and also the name of the participants were not disclosed. As the instructions for completion of these two measures were in English, both scales were adapted to the local spoken language of the participants (Bengali). The reliability and validity of the adapted scale has been provided in the description of the measures above.

In the second phase of the study, the first author contacted school administrators concerning the purpose of the study. Only the Perception of Communication Satisfaction was directly administered to the non-delinquent participants in the school environment by the first author and under close supervision by teachers. In order to maintain the parity with the other group of the total sample, instructions were provided in the Bengali language to this group as well. Consent was taken from each of the students before initiating the procedure. After collecting the data, token gifts (worth 50 INR or $£ 0.75$ ) were provided to each of the participants.

Results

The statistical software SPSS version 17.0 was used to carry out the analysis. Firstly means, standard deviations and t-tests were calculated for both maternal and paternal perceived communication and the t-test result proved to be significant. The result is shown in Table 2 below. 
Table 2 Mean, Standard Deviation and t-test of Delinquent $(n=100)$ and NonDelinquent $(n=100)$ Sample

\begin{tabular}{llll}
\hline & Mean & $\begin{array}{l}\text { Standard } \\
\text { Deviation }\end{array}$ & t-test \\
\hline $\begin{array}{l}\text { Mother's PCS } \\
\text { - Delinquent }\end{array}$ & 45.44 & 8.83 & $9.62^{* *}$ \\
- Non-Delinquent & 61.86 & 6.3 & \\
Father's PCS & & & $7.61^{* *}$ \\
- Delinquent & 46.21 & 7.52 & \\
- Non-Delinquent & 56.97 & 9.4 & $2.93^{* *}$ \\
No. of Siblings & & & \\
- Delinquent & 3 & 3.32 & $23.84^{* *}$ \\
- Non-Delinquent & 2 & 2.51 & \\
Family Income & & 394.08 & \\
- Delinquent & 4820 & 584.33 & \\
- Non-Delinquent & 6500 & & \\
\hline *p $\leq .05 ; * * 0.01$ & & &
\end{tabular}

From the mean score of both the groups, it was clear that there is a discrepancy between them in terms of their perception of how satisfactory are the parental communication. The mean score for the non-delinquent group was higher by comparison to the delinquent group - the former's experiencing better PCS than the latter. The t-test was significant at a .01 level which led the researchers to believe that the perception of communication with parents was much better in the non-delinquent group as compared to the delinquent group. The Table also provided the t-test value for the delinquent and non-delinquent sample on some of the demographic variables, such as number of offspring and family income, and the t-test values are again significant in nature.

A three-way ANOVA (Table 3) was conducted on the scores obtained from the delinquent sample only, with perception of maternal communication, paternal communication and age as the independent variables, and delinquency (as measured by Behavior Deviance Scale) as the dependent variable. 
Table 3 Three - way ANOVA analyses: Maternal communication by Paternal communication by Age as factors and Delinquency as the Dependent variable Delinquent Sample.

\begin{tabular}{lll}
\hline Source & F-value & Sig. \\
\hline Factor & & \\
PCS (M) & $5.11^{*}$ & 0.027 \\
PCS (F) & $4.29^{*}$ & 0.03 \\
AGE & $3.73^{*}$ & 0.05 \\
Interaction terms & & \\
PCS (M) * AGE & 0.47 & 0.496 \\
PCS(F) * AGE & 0.17 & 0.89 \\
PCS(M) ${ }^{*}$ PCS(F) & $3.38^{*}$ & 0.05 \\
\hline${ }^{*} \mathrm{P} \leq 0.05 ; * * 0.01$ & &
\end{tabular}

A significant main effect was found for all the factors, i.e. perception of maternal communication, $\mathrm{F}(1,93)=5.11, \mathrm{p}<0.027$; perception of paternal communication, $\mathrm{F}(1$, $93)=4.29, p<0.03$; age of the adolescent, $F(1,93)=3.73, p<0.05$. This indicates that all three factors had an impact on the development of delinquent behavior among the adolescents from our group. No significant interaction effects were found between mother communication age and father communication age of the adolescent. Therefore, it can be inferred that a satisfactory parental communication is crucial throughout the adolescence period. A significant interaction effect was found between mother adolescent and father adolescent communication, $F(1,93)=3.38, p$ $<0.05$. This indicates that a particular level (low/high) of one independent variables (father's PCS) is associated with a particular level of the other independent variable's (mother's PCS) impact on delinquency, i.e. they both, in conjunction, raise or lower the magnitude of the dependent variable (the BDS score).

A graphical representation indicates the interaction effect clearly. Figure 1 depicts that when both PCS from mother and father was poor, behavior deviation scores were the highest. When both were high it was lowest. The combination of poor score from one parent and good score from another parent produces intermediate BDS scores. 
Figure 1 Line graph representing the interaction effect between Maternal and Paternal Communication

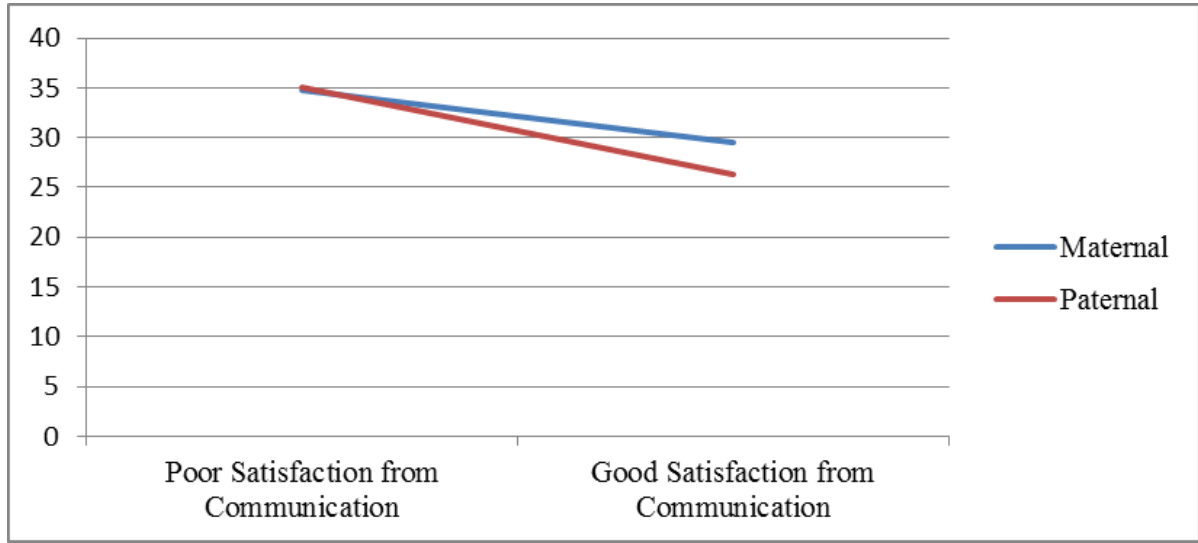

From the mean score, shown in Table 4 it can be observed that adolescents who declare a satisfactory communication with their mother have a lower delinquency score and those who experience unsatisfactory communication has higher delinquency scores. The situation is similar for father - adolescent communication. With respect to age, it was found that early adolescents (11-14yrs) had higher delinquency scores compared to late adolescents (15 - 18yrs).

Table 4 Descriptive statistics of the factors (Maternal communication, Paternal communication and Age) - Delinquent Sample

\begin{tabular}{lrrrrrr}
\hline & Maternal Communication & \multicolumn{4}{l}{ Paternal Communication } & Age \\
& Low $(n=84)$ & High $(n=16)$ & Low $(n=87)$ & High $(n=13)$ & $(11-14)$ & $(15-18)$ \\
\hline Mean & 34.8 & 29.5 & 35.13 & 26.30 & 31.29 & 24.25 \\
SD & 4.23 & 3.77 & 3.91 & 5.24 & 2.12 & 2.58 \\
\hline
\end{tabular}

Since the interaction effect between mother communication - father communication was significant in nature, individual t-tests were carried out between various combinations of maternal and paternal communication in order to understand which parenting combination is contributing most to the development of delinquency and which is the least contributing combination. Here as well in all the four conditions, the Perception of Communication Satisfaction was the Independent Variable and Behavior 
Deviance Score was the Dependent variable. Table 5 represents the t-test values along with the Levene's test of homogeneity of variance (as the group size was very unequal).

Table 5 t-test representing the differences among various combinations of maternal and paternal communication - Delinquent Sample

\begin{tabular}{lll}
\hline Source & t-test & Levene's test \\
\hline Poor Communication (M) * Poor Communication (F) & $5.82^{* *}$ & .695 \\
Good Communication (M) * Poor Communication (F) & $2.44^{*}$ & .611 \\
Poor Communication (M) * Good Communication (F) & $3.39 *$ & .657 \\
Good Communication (M) * Good Communication (F) & $1.95^{*}$ & .406 \\
\hline
\end{tabular}

Note: $M$ - Mother; F - Father. ${ }^{*} \mathrm{p} \leq 0.05 ;{ }^{* *} \mathrm{p} \leq 0.01$; PCS - Independent Variable, BDS Dependent Variable.

All Levene's test values were non-significant in nature, indicating that the assumption of equality of variance has been met. It was observed from the t-tests, that adolescents indicating poor communication with both parents had the highest rate of delinquency; whereas adolescents indicating good communication with both the parents had the lowest rate of delinquency.

\section{Discussion}

The purpose of this study was to assess how perception of satisfactory maternal and paternal communication is separately, as well in combination, related to adolescent problem behaviors, such as delinquency. First of all a comparative analysis was conducted between delinquent and non-delinquent adolescents regarding their perception of satisfactory communication with their parents. A significant difference between the two groups of adolescents concerning parental communication was observed. Both mother and father (perception of) satisfactory communication is poor in delinquent adolescents as compared to their counterparts. These findings are consistent with those of earlier studies conducted by Barnes et al., (1994), Johnson et al., (1995), Clark and Shields (1997), Liu (2003), Musitu Ochoa et al. (2007). From the 
sample characteristics it can be observed that the parents of delinquent adolescents are less educated, their number of offspring and as a result there is a higher economic strain in delinquent families as compared to families with non-delinquent adolescents. All these in turn hamper a healthy parent adolescent communication, as parents are not able to spend quality time with their children (Rueter \& Koerner, 2008). According to Conger and his colleagues (Conger et al., 1992; Conger, Conger, \& Elder, 1993; Conger, Ge, Elder, Lorenz, \& Simons, 1994) economic hardship (often tied to parents' education level, number of dependents, etc.) is related to a lack of parent-adolescent bond and, in turn, strongly associated with developmental and adjustment problems in the case of adolescents.

In the next phase of the study, mother's and father's separate communication patterns with the delinquent adolescent were studied as well as how they are linked to delinquency. Adolescents' perception of satisfactory maternal as well as paternal communication was analyzed separately and suggested a significant relationship with delinquency. Therefore it can be said that both mother's and father's perceived satisfactory communication exerts a strong influence on delinquent behavior in the case of adolescents and therefore can also act as a protective factor against delinquency. These findings add to previous research conducted by Xiao et al., 2011 (as data were not available in the mentioned study to distinguish between maternal and paternal communication). From the present study it can be further concluded that both parents' communication had an interaction effect, which is significant in nature, indicating that if the adolescent receives satisfactory communication from at least one of the parents, then that may result in low levels of delinquency. Delinquent behavior is least found when the adolescent perceives satisfactory communication from both the parents. This finding is in line with a study conducted by Barnes and Olson (1985), in which they found that healthy communication may indicate an overall better relationship between parents and adolescents, which may serve as a protective factor for children against the development of depression and anxiety and engagement in antisocial activities. Therefore it can be said that perception of satisfactory communication from both parents is essential, but if the adolescent is having a satisfactory communication level with at least one of the parents, then that can compensate the lack or poor communication with the other parent (compared to the condition where both parents have a poor communication with their children).

Age was also found to have a significant effect on delinquency. The magnitude of mean score further suggested that delinquency rates are higher in early adolescence 
(11 - 14 years) as compared to late adolescence (15- 18 years). When children enter adolescence other people such as peers and romantic partners become more important than parents. It is during this phase when their transition into adulthood begins and they feel independent from their parents and also, due to this sudden 'freedom' from the stricter rules of childhood, they may get involved in deviant behavior. The present finding is consistent with previous research. There is substantial evidence that the early period of adolescence is associated with problem behaviors such as early sexual activity, delinquency, bullying, truancy, disruptive behavior and violent behavior (Caspi, Lynam, Moffitt, \& Silva, 1993; Cota-Robles, Neiss, \& Rowe, 2002; Flannery, Rowe, \& Gulley, 1993; Graber, Lewinsohn, Seeley, \& Brooks-Gunn, 1997; Haynie, 2003; KaltialaHeino, Marttunen, Rantanen, \& Rimpela, 2003; Obeidallah, Brennan, Brooks-Gunn, \& Earls, 2004). According to Jessor (1984), early adolescence is a period of rapid change, when adolescents are struggling to deal with issues such as identity development, peer group membership, pubertal development and changing social roles. Coupled with the earlier mentioned reasons, there seem to be an increased proneness to engage in risky behavior during this stage. Therefore, the findings of the present study hold true in a non-Western country as well. The interaction effect of age with maternal communication as well as paternal communication was non-significant in nature, indicating that a healthy parent adolescent communication is not only important in the early phase of adolescence, but it is crucial in late adolescence as well (Hoeve, Dubas, Gerris, Laan, \& Smeenk, 2011).

Finally, individual t-tests were carried out in order to analyze more specifically which combination of parent-adolescent communication is linked to the highest rate of delinquency. These analyses revealed that perception of poor maternal as well as paternal communication is highly linked to delinquency, whereas perception of good maternal and paternal communication is linked to the lowest levels of delinquency. Also it was observed that perception of satisfactory mother adolescent communication is more important than father-adolescent communication. This finding is contrary to some previous studies (Jacob \& Johnson, 1997). This rather unexpected finding can be explained on the basis of cultural background of the adolescents in this study. One of the central features of Indian family is the centrality of family, where interdependence is very high and each and every family member depends on others. In an Indian context the father is usually the bread earner of the family and the mother takes care of the children, she is the first love object in their life and children also depend on their mother for fulfillment of various needs and wishes. In fact this bond continues even in 
adulthood, when the children take the consent of their parents for every major decision. In the absence of this mutual love, the child gets diverted toward delinquency. Therefore, good maternal communication and poor paternal communication may trouble the adolescent, but not up to an alarming state due to their mother's support, care and love. It seems to act as a buffer against deviant behaviors - such as delinquency. In contrast, poor maternal good paternal communication is not an equally protective buffer. So, a healthy mother-adolescent (boy) communication appears to be a stronger more protective factor against delinquency.

Some important limitations of this study should be noted. First, the sample only included Bengali families from an Eastern metropolitan city in India. As India is a diverse country, where every region has its own unique culture, the findings of this study may not be generalized to other part of the country. Second, this study was conducted only on male adolescents not female adolescents because of the unavailability of female delinquents in the police official records. Therefore, future research should be undertaken to extend this research on different sample. Third, this study only investigated parent - adolescent interaction and adolescent delinquent behavior and did not examine any other mediating factors, such as communication with siblings or grandparents. Moreover, it considered perceived communication rather than observing actual communication processes between parents and adolescents.

Despite these limitations, the biggest strength of this study is represented by the exploration of perceptions of satisfactory communication with both parent's. The current study also contributed to the paucity of research especially in an Indian context. Furthermore, it focused on the segment of uneducated and poverty stricken mass, who are generally unable to avail wealth and opportunities for holistic growth of their off-spring. It is suggested here that wholesome parent child relationships can be a real antidote against delinquency. Also both parents should be equally encouraged to enhance their communication skill with their son in order to develop a positive interpersonal/ social support system within the family. As this help the adolescent to develop a more mature and responsible attitude towards society. Hence various awareness programs should be implemented nationwide focused on family-life education. School, community leaders, agencies and organizations are in an ideal position to assist parents not only in improving their communication skills, but also in augmenting their marital and family strengths. 


\section{Acknowledgements}

The authors would like to acknowledge the Superintendent, Mr. Supratim Sinha (Dhrubashram - State Government Observation and Special Home) and the respective staff of the institution. They would also like to thank the Board members of the Juvenile Justice Board, Kolkata, India for giving them permission to visit the Juvenile Home for the purpose of data collection.

\section{References}

Bachman, J. G. (1970). Youth in Transition. The impact of family background and intelligence on tenth grade boys. Ann Arbor, Michigan: Institute for Social Research. vol.2.

Bandura, A., \& Walters, R. H. (1959). Adolescent aggression. New York: Ronald Press.

Barnes, G. M., Farrell, M. P., \& Banerjee, S. (1994). Family influences on alcohol abuse and other problem behavior among black and white adolescents in a general population sample. Journal of Research on Adolescence, 4, 183-201. doi:10.1207/s15327795jra0402_2

Barnes, H. L., \& Olson, D. H. (1985). Parent-adolescent communication the circumplex model. Child Development, 56, 438-447. doi:10.2307/1129732

Brage, D., \& Meredith, W. (1994). A causal model of adolescent depression. The Journal of Psychology, 128, 455-468. doi:10.1080/00223980.1994.9712752

Caspi, A., Lynam, D. R., Moffitt, T. E., \& Silva, P. (1993). Unraveling girls' delinquency: Biological, dispositional, and contextual contributions to adolescent misbehavior. Developmental Psychology, 29, 19-30. doi:10.1037/0012-1649.29.1.19

Office of the Registrar General and Census Commissioner. (2011). Cities having population 1 lakh and above, Census 2011 (Ministry of Home Affairs, Government of India). Retrieved from http://www.censusindia.gov.in/201 1-prov-results/paper2vol2/data_files/India2/Table_2_PR_Cities_1Lakh_and_Above.pdf

Cernkovich, S., \& Giordano, P. (1987). Family relationships and delinquency. Criminology, 25(2), 295-319. doi:10.1111/j.1745-9125.1987.tb00799.x 
Chauhan, N. S., \& Aurora, S. (1989). Behavior Deviance Scale for Adolescence. Mapa. Meerut.

Chrispin, M. C. (1998). Resilient adaptation of church-affiliated young Haitian immigrants: A search for protective resources (Doctoral dissertation, Teachers College, Columbia University, 1998). Dissertation Abstracts International. (University Microfilm International No. AA199-09411).

Clark, R. D., \& Shields, G. (1997). Family communication and delinquency. Adolescence, $32,81-92$.

Collins, W. E., Newman, B. M., \& Mckenry, P. C. (1995). Intrapsychic and interpersonal factors related to adolescent psychological well-being in stepmother and stepfather families. Journal of Family Psychology, 9, 433-445. doi:10.1037/0893-3200.9.4.433

Conger, R. D., Conger, K. J., \& Elder, G. H., Jr. (1993). Family economic stress and adjustment of early adolescent girls. Developmental Psychology, 29, 206-219. doi:10.1037/0012-1649.29.2.206

Conger, R. D., Conger, K. J., Elder, G. H., Jr., Lorenz, F. O., Simons, R. L., \& Whitbeck, L. B. (1992). A family process model of economic hardship and adjustment of early adolescent boys. Child Development, 63, 526-541. doi:10.2307/1131344

Conger, R. D., Ge, X., Elder, G. H., Jr., Lorenz, F. O., \& Simons, R. L. (1994). Economic stress, coercive family process, and developmental problems of adolescents. Child Development, 65, 541-561. doi:10.2307/1131401

Cota-Robles, S., Neiss, M., \& Rowe, D. (2002). The role of puberty in violent and nonviolent delinquency among Anglo American, Mexican American, and African American Boys. Journal of Adolescent Research, 17, 364-376.

doi:10.1177/07458402017004003

Demo, D. H., Small, S. A., \& Savin-Williams, R. C. (1987). Family relations and the selfesteem of adolescents and their parents. Journal of Marriage and the Family, 49, 705715. doi:10.2307/351965

Enger, J. M., Howerton, D. L., \& Cobbs, C. R. (1994). Internal/external locus of control, self-esteem, and parental verbal interaction of at-risk black male adolescents. The Journal of Social Psychology, 134, 269-274. doi:10.1080/00224545.1994.9711730 
Flannery, D. J., Rowe, D. C., \& Gulley, B. L. (1993). Impact of pubertal status, timing, and age on adolescent sexual experience and delinquency. Journal of Adolescent Research, 8, 21-40. doi:10.1177/074355489381003

Garnefski, N., Rieffe, C., Jellesma, F., Terwogt, M. M., \& Kraaij, V. (2007). Cognitive emotion regulation strategies and emotional problems in $9-11$ year old children: The development of an instrument. European Child \& Adolescent Psychiatry, 16, 1-9. doi:10.1007/s00787-006-0562-3

Glueck, S., \& Glueck, E. (1962). Family Environment and Delinquency. Boston: Houghton Mifflin.

Gold, M. (1963). Status forces in Delinquent boys. Ann Arbor, Michigan: Institute of Social Research.

Graber, J. A., Lewinsohn, P. M., Seeley, J. R., \& Brooks-Gunn, J. (1997). Is psychopathology associated with the timing of pubertal development? Journal of the American Academy of Child and Adolescent Psychiatry, 36, 1768-1776. doi:10.1097/00004583-199712000-00026

Granic, I., Dishion, T. J., Hollenstein, T., \& Patterson, G. R. (2002). The family ecology of adolescence: A dynamic system perspective on normative development. In G. R. Adams \& M. Berzonsky (Eds.), The Blackwell handbook of adolescence (pp. 60-91). Oxford, UK: Blackwell.

Greenberg, M., Siegel, J., \& Leitch, C. (1983). The nature and importance of attachment relationships to parents and peers during adolescence. Journal of Youth and Adolescence, 12, 373-386. doi:10.1007/BF02088721

Guilamo-Ramos, V., Jaccard, J., Dittus, P., \& Bouris, A. M. (2006). Parental expertise, trustworthiness, and accessibility: Parent-adolescent communication and adolescent risk behavior. Journal of Marriage and the Family, 68, 1229-1246. doi:10.1111/j.17413737.2006.00325.x

Hanson, M. (1986). Healthy single parent families. Family Relations, 35, 125-132. doi:10.2307/584291

Hartos, J., \& Power, T. (2000). Association between mother and adolescent reports for assessing relations between parent-adolescent communication and adolescent 
adjustment. Journal of Youth and Adolescence, 29, 441-450.

doi:10.1023/A:1005158425861

Hawley, L. E., Shear, C. L., Stark, A. M., \& Goodman, P. R. (1984). Resident and parental perceptions of adolescent problems and family communications in a low socioeconomic population. The Journal of Family Practice, 19, 651-655.

Haynie, D. L. (2003). Contexts of risk? Explaining the link between girls' pubertal development and their delinquency development. Social Forces, 82, 355-397. doi:10.1353/sof.2003.0093

Hecht, M. L. (1978). The conceptualization and measurement of Interpersonal Communication Satisfaction. Human Communication Research, 4(3), 253-264. doi:10.1111/j.1468-2958.1978.tb00614.x

Hirschi, T. (1969). The causes of delinquency. Berkeley University of California Press.

Hoeve, M., Dubas, J. S., Eichelsheim, V.I., Laan, P. H., Smeenk, W., \& Gerris, J. R. M. (2009). The relationship between parenting and delinquency: a meta-analysis. Journal of Abnormal Child Psychology, 37(6), 749-775. doi:10.1007/s10802-009-9310-8

Hoeve, M., Dubas, J. S., Gerris, J. R. M., Laan, P. H., \& Smeenk, W. (2011). Maternal and paternal parenting styles: Unique and combined links to adolescent and early adult delinquency. Journal of Adolescence, 34(5), 813-827.

doi:10.1016/j.adolescence.2011.02.004

Holstein, C. (1972). The relation of children's moral judgement level to that of their parents and to communication patterns in the family. In R. Smart \& M. Smart (Eds.), Readings in child development (pp. 484-494). New York: Macmillan.

Jaccard, J., Dodge, T., \& Dittus, P. (2002). Parent-adolescent communication about sex and birth control: A conceptual framework. In S. Feldman \& D. A. Rosenthal (Eds.), Talking sexuality: Parent-adolescent communication (pp. 9-41). San Francisco, CA: Jossey-Bass.

Jacob, T., \& Johnson, S. (1997). Parenting influences on the development of alcohol abuse and dependence. Alcohol Health and Research World, 21, 204-209. 
Jessor, R. (1984). Adolescent development and behavioral health. In J. Matarazzo, S. Weiss, J. Herd, N. Miller \& S. Weiss (Eds.), Behavioral health: A handbook of health enhancement and disease prevention. (pp. 69-90). New York: Wiley.

Johnson, R. A., Su, S. S., Gerstein, D. R., Shin, H. C., \& Hoffman, J. P. (1995). Parental influences on deviant behavior in early adolescence: A logistic response analysis of age and gender-differential effects. Journal of Quantitative Criminology, 11, 167-193. doi:10.1007/BF02221 122

Johnson, S. M., \& Lobitz, G. K. (1974). Parental manipulation of child behavior in home observation. Journal of Applied Behavior Analysis, 7, 23-31. doi:10.1901/jaba.1974.7-23

Kafka, R. R., \& London, P. (1991). Communication in relationships and adolescent substance use: The influence of parents and friends. Adolescence, 26, 587-598.

Kaltiala-Heino, R., Marttunen, M., Rantanen, P., \& Rimpela, M. (2003). Early puberty is associated with mental health problems in middle adolescence. Social Science \& Medicine, 57, 1055-1064. doi:10.1016/S0277-9536(02)00480-X

Kandel, D. B., \& Davies, M. (1982). Epidemiology of depressive mood in adolescents. Archives of General Psychiatry, 39, 1205-1212. doi:10.1001/archpsyc.1982.04290100065011

Kotchick, B. A., Dorsey, S., Miller, K. S., \& Forehand, R. (1999). Adolescent sexual risktaking behavior in single-parent ethnic minority families. Journal of Family Psychology, 13, 93-102. doi:10.1037/0893-3200.13.1.93

Lerman, P. (1968). Evaluating institutions for delinquents. Social Work, 13, 55-64.

Liu, Y. L. (2003). Parent-child interaction and children's depression: The relationships between parent-child interaction and children's depressive symptoms in Taiwan. Journal of Adolescence, 26, 447-457. doi:10.1016/S0140-1971 (03)00029-0

Masselam, V. S., Marcus, R. F., \& Stunkard, C. L. (1990). Parent-adolescent communication, family functioning, and school performance. Adolescence, 25, 725737. 
Miller, K. E., King, C. A., Shain, B. N., \& Naylor, M. W. (1992). Suicidal adolescents' perceptions of their family environment. Suicide \& Life-Threatening Behavior, 22, 226239.

Musitu Ochoa, G., Estevez Lopez, E., \& Emler, N. P. (2007). Adjustment problems in the family and school contexts, attitude towards authority, and violent behavior at school in adolescence. Adolescence, 42, 779-794.

Obeidallah, D., Brennan, R. T., Brooks-Gunn, J., \& Earls, F. (2004). Links between pubertal timing and neighborhood contexts: Implications for girl's violent behavior. Journal of the American Academy of Child and Adolescent Psychiatry, 43, 1460-1 468.

doi:10.1097/01.chi.0000142667.52062.1e

Parker, G., Tupling, H., \& Brown, L. B. (1979). A parental bonding instrument. The British Journal of Medical Psychology, 52, 1-10. doi:10.1111/j.2044-8341.1979.tb02487.x

Rueter, M. A., \& Koerner, A. T. (2008). The effect of family communication patterns on adopted adolescent adjustment. Journal of Marriage and the Family, 70, 715-727. doi:10.1111/j.1741-3737.2008.00516.x

Smith, C., \& Krohn, M. (1995). Delinquency and family life among male adolescents: the role of ethnicity. Journal of Youth and Adolescence, 24(1), 69-93.

doi:10.1007/BF01537561

Stanley, S. (1978). Family education: A means of enhancing the moral atmosphere of the family and the moral development of adolescents. Journal of Counseling Psychology, 25, 110-118. doi:10.1037/0022-0167.25.2.110

Steinberg, L. (1988). Reciprocal relation between parent-child distance and pubertal maturation. Developmental Psychology, 24, 122-128. doi:10.1037/0012-1649.24.1.122

Videon, T. M. (2005). Parent-child relations and children's psychological well-being: do dad matters? Journal of Family Issues, 26(1), 55-78. doi:10.1177/0192513X04270262

Warr, M. (1993). Parents, peers and delinquency. Social Forces, 72(1), 247-264.

Xiao, Z., Li, X., \& Stanton, B. (2011). Perception of parent-adolescent communication within families: It is a matter of perspective. Psychology Health and Medicine, 16(1), 5365. doi:10.1080/13548506.2010.521563 
Yu, S. L., Clemens, R., Yang, H. M., Li, X. M., Stanton, B., Deveaux, L., . ., \& Harris, C. (2006). Youth and parental perceptions of parental monitoring and parent-adolescent communication, youth depression, and youth risk behavior. Social Behavior and Personality, 34, 1297-1310. doi:10.2224/sbp.2006.34.10.1297

Youniss, J., \& Smollar, J. (1985). Adolescent relations with mothers, fathers and friends. Chicago: University of Chicago Press.

About the authors

Tanusree Moitra, M.A. (Research Fellow), Doctoral Fellow in the Department of Applied Psychology, University of Calcutta, India. Her major interest is to understand the causes of juvenile delinquency in India. She completed are undergraduate in Psychology at Delhi University, India. After that she did her Master's in Applied Psychology at the University of Calcutta. She also completed a certificate course in Psychology at Northeastern University, Boston. USA. Currently pursuing her doctoral research from University of Calcutta with a National Fellowship for her work from the Bureau of Police Research \& Development, Ministry of Home Affairs, Govt. of India on Oct'2009. Email: tanusree_moitra@yahoo.co.in

Indrani Mukherjee, Ph.D., Professor in the Department of Applied Psychology, University of Calcutta, India. Her major research interests relate to women and adolescentrelated social issues in India. She gained her undergraduate, Master's and Ph.D from the University of Calcutta and currently she is been teaching at the University along with being involved in research. Email: Callkol@yahoo.co.in 